\title{
ТРАНСФОРМАЦІЯ ЖАНРУ НАРИСУ У НОВИХ МЕДІА
}

\author{
Антоніна Іващук \\ Національний авіаційний університет, \\ пр. Космонавта Комарова, 1, 03680, Київ, Україна \\ e-mail:Iva.tonya@gmail.com \\ https://orcid.org/0000-0003-0209-148X
}

Стаття присвячена проблемам та перспективам розвитку й подальшої трансформації подорожнього нарису. Розглянуто особливості створення матеріалу, який був би затребуваним аудиторією; визначено комплекс чинників, які обумовлюють успішність нарису в сучасних засобах масової інформації; виокремлено підходи до збору унікальної інформації; узагальнена теоретична база щодо дефініції «нарис». На сьогодні виникає нагальна потреба в дослідженнях трансформації жанрових форм, адже 3 тенденцією збільшення популярності нових медіа й зменшення цільової аудиторії друкованих засобів масової інформації доцільно з'ясувати, як написати тревел-публікацію або портретний нарис так, щоб вони були цікавими та затребуваними аудиторією. Нові медіа, безумовно, дають можливість використовувати не тільки текст, а й зображення, відео та аудіо. Сьогодні має місце тенденція щодо несприйняття аудиторією великих текстів, тому жанрова форма потребує змін та адаптування в різних видах і каналах комунікації.

Ключові слова: нарис, подорожній нарис, портретний нарис, жанри, цільова аудиторія, нові медіа, художньо-публіцистична група жанрів, соціальні мережі.

Сьогодні можемо констатувати факт трансформації й варіативності журналістських жанрів у друкованих й інтернет-ЗМІ. Така тенденція зумовлена новими викликами часу та затребуваності на ринку інформації коротких, цікавих та оперативно поданих матеріалів, що унеможливлює дотримання жанрових форм більшості 3 них. Безумовно стрімкий розвиток туризму та глобалізаційні процеси впливають на трансформацію й такого жанру, як подорожній нарис. На сьогодні цей жанр журналістики набуває все більшої популярності, а тому потребує детального наукового дослідження.

Незважаючи на достатню кількість досліджень, присвячених нарису, цей жанр досі потребує детального вивчення й аналізу. Найбільш змістовно нарис було досліджено у працях Т. Беневоленської, М. Васьківа, М. Глушкова, О. Гусєвої, М. Кіма, Н. Маслової, Н. Паволвої, Ю. Полєжаєва, О. Тертичного, Е. Фюрзіха та ін.

Мета статті полягає у визначенні жанрових та стилістичних особливостей нарису в умовах глобалізації та тенденцій сьогодення. Для досягнення мети ставимо перед собою такі завдання: проаналізувати дефініції термінів «нарис», «подорожній

(C) Іващук А., 2019 
нарис», «портретний нарис», «травелог», «тревел-журналістика»; з'ясувати фактори впливу глобалізації на розвиток подорожнього нарису; визначити та охарактеризувати стилістичні й жанрові особливості сучасного нарису та нарису в історичній площині; проаналізувати вимоги нових медіа до художньо-публіцистичної жанрової форми, а саме - нарису.

Історія появи нарису грунтовно не досліджена. У багатьох країнах цей жанр має іншу назву - есе, подорожнє есе, тревел-текст тощо. Нарисову форму та есе в західній літературі не диференціюють як окремі жанри. Проте в Україні саме жанр нарис визначається, як такий, який має свої особливості й ознаки. А це означає, що специфіка написання й цілі в жанрах есе та нарисі можуть бути різними, з огляду на світовий досвід. Також важливо відзначити, що популярність жанру, як і його виникнення, в тих чи інших країнах, у різні часи виявлялися по-різному.

У той же час, Н. Маслова, як і більшість учених, стверджує, що подорожній нарис відноситься до найбільш ранніх форм текстів, що ознаменували становлення журналістики. А подібна подорожньому нарису форма відображення дійсності була чи не першою в художній літературі $[1$, с. 5$]$.

На території сучасної України зародження подорожнього нарису почалося ще в часи Київської Русі. Згідно з дослідженнями М. Прокоф’єва, у Київській Русі були поширені твори про реально-історичні події. За змістом і формальними ознаками, їх можна назвати нарисовими, спираючись на сьогоденні жанрові визначення. Провідне місце серед них належало запискам про подорожі, їх називали в давнину «ходіннями» [2].

Подорожній нарис перетворювався в певну жанрову форму, насичену суб'єктивним початком, відбулося введення в нарис малих жанрів літератури, раніше не характерних для цього жанру. Особливе значення мала при цьому різноманітна взаємодія нарисових й епістолярних структур: вона визначала характер поєднання описових, аналітичних, довідково-інформативних, а з іншого боку - ліричних, сюжетно-белетристичних елементів, вона ж сприяла синтезу в літературі про подорожі різних документальних жанрів (мемуарного, щоденникового, епістолярного) [3].

Новим етапом розвитку подорожнього нарису стала поява туризму як галу3i. Ю. Полєжаєв встановив, що «на території України період з 1841 до 1914 рр. став часом виникнення перших туристських організацій на території Російської й Австро-Угорської імперій. Він характеризувався окремими прикладами використання екскурсій, походів, подорожей із метою освіти та збирання науково-географічної, краєзнавчої інформації про різні райони та рідний край» [4, с. 107-108]. Преса друкувала переважно твори мандрівників-професіоналів - письменників, істориків та етнографів (I. Вагилевича, Я. Головацького, І. Нечуя-Левицького, І. Франка), - але подекуди можна було знайти і студентські нариси.

Окремий «вид» подорожнього нарису в Україні можна виділити у радянські часи XX століття. Серед найвідоміших його творців Б. Антоненко-Давидович, I. Микитенко, О. Полторацький, Т. Масенко, І. Лісовий, I. Дубинський та ін. Вони писали про громадянську війну, місця заслання, революційний рух, нариси на виробничі теми, дорожні спостереження. Теми подорожніх нарисів: люди села, їхня праця та досягнення, організація виробництва та всього господарського життя в колгоспах, вивчення та поширення кращого досвіду в інших країнах. Нариси відзначалися емоційністю, описом деталей, власними враженнями. 
Глобалізаційні процеси у світі підштовхують журналістів до пошуків нових тем для матеріалів і форм їх подачі. 3'являється й окреме поняття - тревел-журналістика, - що означає особливий напрямок журналістики, який надає масовому споживачеві інформацію про подорожі, зачіпає теми історії, географії, культури, мистецтва, туризму, етики, філософії та багато інших галузей. Відповідаючи вимогам часу, журналістські жанри тяжіють до зменшення тексту й збільшення візуальних елементів: фотографій, малюнків, таблиць, діаграм тощо.

Сьогодні часто плутають поняття травелог і подорожній нарис, вважаючи що це - одне й те саме. Насправді травелог - це літературний жанр, а подорожній нарис - журналістський. Травелог - це книга, подорожній нарис - декілька сторінок. Оксфордський передовий тлумачний словник сучасної англійської мови подає «travelogue» як фільм, книгу чи лекцію про відвідувані місця з досвіду мандрівника. Англійський учений Й. Борм переконує в доцільності розмежування травелогу та літератури подорожей, оскільки травелог належить до літератури нон-фікшн [5]. Окрім того, західні дослідники стверджують, що травелог як тематичне утворення сьогодні не можна розглядати в контексті літературної журналістики, яка передусім відрізняється видовими характеристиками.

У нових медіа нарис неможливо уявити без фотографій, відео або аудіо матеріалів, віртуальних карт, інфографіки загалом. Таким чином автори полегшують сприйняття інформації й дозволяють подорожувати з собою, або візуалізувати портрет людини, про яку йдеться у портретному нарисі.

Отже, нарис пройшов довгий шлях свого становлення і розвитку. При цьому він виявив себе як жанр, що швидко пристосовується до сучасних тенденцій. Але основний задум нарису залишається незмінним - відкривати нові світи, ділитися досвідом і враженнями від подорожі; описувати людину, щоб передати аудиторії не тільки зовнішні риси, а й характер, звички, особливості, значення для суспільства. Протягом розвитку й трансформації жанру змінювалися форма, стиль і підхід до написання.

Сьогодні в мовному середовищі спостерігається активний процес жанротворення. Одні жанри замінюються іншими, деякі трансформуються, треті взаємодіють і синтезуються. Це не є випадковим явищем, адже, як справедливо помічає А. М. Тепляшина, «жанр фіксує зрушення у духовному житті суспільства і змінюється разом 3 ним» [6, с. 129].

Жанрова специфіка сучасного подорожнього нарису полягає в модифікації сюжетно-композиційної структури нарису, в яку включені й жанрові компоненти есе, які проявляються в описі й оцінці фактів і подій з точки зору моральних та етичних принципів, автор висловлює власний концептуальний погляд на описувані події та думки на філософські теми [7]. Авторське «Я» присутнє в тексті не стільки через позицію та ідеї, які несе журналіст, скільки через уміння цікаво й захоплююче подавати матеріал, створювати інтригу та «закручений» сюжет.

Науковці вважають, що є спорідненість жанрів нарису та репортажу. Адже в репортажі є яскраве повідомлення про подію, дослідження середовища, збагачене описом деталей. Так само і подорожні записи є в дослідженням середовища, в якому відбуваються події.

В. Козьмин вважає, що подорожній нарис - це певна «мозаїка, складена з окремих образів людей, описів сцен, роздумів і пов'язана лише логікою роз'яснення пока- 
заного явища. А вільне, без сюжету, об’єднання «шматків життя» - типове для жанру нарису» $[8$, c. 56]. Справді, сьогодні трапляються і нариси, позбавленні сюжету та послідовності дій мандрівника. Адже в цьому жанрі все залежить від авторського задуму та мети, обраної композиції.

Науковці виділяють три основні типи композиційних форм відображення навколишньої дійсності в подорожніх нарисах: хронікальна побудова нарису (опис явищ, подій, людського життя в їх часовій послідовності); побудова, заснована на логіці причинно-наслідкових зв’язків (дослідження, аналіз, де немає розповіді точної хронологічної послідовності); вільна форма побудови (складні асоціативні зв’язки й образні узагальнення, зазвичай поєднує в собі елементи обох попередніх типів і характеризується найбільшою поліфонічністю композиційних прийомів і засобів).

Сама дійсність у подорожньому нарисі повинна бути не просто зафіксована, а зображена зримо, в образах. Нарисовець, дотримуючись фактичної основи, моделює своєю уявою картину «відрізка життя». Подорожній нарис репрезентує художньо-публіцистичну модель реального світу.

За дослідженнями О. Гусєвої, для нарису характерна «постійна присутність на першому плані учасника, що роз'яснює, коментує, узагальнює події. У ньому можуть співіснувати і власне оповідне начало, й елементи сценки, і статистичні викладки, і розгорнуті авторські публіцистичні судження. Сьогодні на першому плані в подорожньому нарисі виявляється особистий досвід, суб’єктивний погляд на зміни, що відбулися в житті автора-персонажа. Розповідь від першої особи - форма трансляції особистого достовірного досвіду. Соціальна аналітика приглушена, автори відмовляються від широких узагальнень і порівняно рідко вдаються до прямої публіцистичної оцінки зображуваного» [9].

Сама ж дослідниця помічає, що на початку XXI ст. здійснюється подолання канону, відбувається модернізація нарису, набуття ним нових ознак і властивостей на межі руйнування традиційного жанру (есеїстичність, сповідальність, автобіографізм). Буває, автор узагалі не виявляє себе жодним чином у нарисі - ні прямо, ні опосередковано, а твір цілісності не втрачає.

В умовах сьогодення, конвергенції журналістики, невід'ємною частиною подорожнього нарису стають фото- та відеоматеріали. Часто вони заміщують слова, опис або ж фактично підтверджують їх, «продовжують» сам текст. Така тенденція викликана потребою самих читачів, які більше прагнуть бути «глядачами» і бачити все на власні очі, а не вимальовувати описи автора в своїй уяві.

Усе ж таки, не зважаючи на тенденцію інфотейнменту (тяжіння до інформативності та розважливості), подорожній нарис володіє багатою палітрою тропів, які більшою чи меншою мірою обов'язково $є$ в тексті.

Для сучасного подорожнього нарису все ж таки характерні образність і художність: переплітаються побутові сценки, складні синтаксичні конструкції, філософські та ліричні відступи, діалоги, пряма та непряма мова, експресивна лексика тощо. Дослідники зазначають, що до елементів поетики подорожнього нарису слід відносити деталь, портрет, пейзаж, інтер'єр, домисел, а також авторське «Я», автобіографізм, особистість і характер журналіста, мовно-стилістичне багатство журналістського твору.

Професор О. Гриценко стверджує, що «пейзаж у нарисі працює на зміст і несе глибоку ідею. Картини природи сприяють розкриттю ситуації, служать фоном, на 
якому розгортаються події, вказують на місце і час, створюють локальний колорит, той настрій, ті почуття, які викликає природа у героя, посилюють ліризм і драматизм оповіді, увиразнюють ідею твору» [10, с. 266].

Деталь у нарисовому творі є одним із засобів художньої типізації. За допомогою вдало знайденої деталі можна передати характерні риси зовнішності людини, його мови, манери поведінки і т.д. За допомогою яскравої деталі можна замінити цілі описові фрагменти. Правдива деталь допомагає повніше зобразити предмет, підвищує художність твору, конкретизує його. Іноді тільки за допомогою однієї деталі можна відтворити повний образ або певний настрій.

Портрет у публіцистиці часто виступає своєрідним аналогом характеру героя. Він дає можливість побачити героя і цим самим стимулює читацьку уяву. Портретна характеристика безпосередньо пов'язана з психологічними особливостями. Основні вимоги - документальна точність відображення.

Однією з особливостей подорожніх нарисів $є$ те, що вони надзвичайно багаті різноманітними тропами. Серед найпопулярніших та найуживаніших троп $\epsilon$ епітет, метафора, порівняння, діалектизм, перифраз, риторичні фігури, антитеза; подекуди - алегорія, іронія, гіпербола.

На сьогодні велика кількість блогерів у соціальних мережах працюють в цьому жанрі: пишуть пости з власних подорожей де діляться корисними посиланнями, описами цікавих місць, традицій та особливостями тієї чи іншої країни. Ілюструють великою кількістю фотографій, іноді подають таблиці та діаграми, порівнюючи, аргументуючи, переконуючи у своїх матеріалах. Наприклад, на нашу думку, сьогодні є такі найвідоміші блогери в Україні, які працюють 3 жанром нарису:

- О. Ладанівський - описує власні подорожі Україною та іншими країнами світу. У нього 129 тисяч підписників в Інстаграмі та близько 10 тисяч уподобань під кожним постом;

- В. Потоцька - окрім публікацій фотографій з країн різного світу, авторка дає корисні поради щодо кожної з локацій, ділиться власними вподобаннями кухні, готелів, екскурсій. Має 166 тисяч підписників в Інстаграмі, які активно лайкають та коментують дописи.

- В. Пасько - блогерка розказує про найцікавіші місця планети, дає корисну інформацію, описує власні враження від подорожей, які ілюструє власними фото. Має близько 110 тисяч підписників в Інстаграмі.

Трансформовані нариси набувають популярності не тільки в соціальних мережах, їх можна зустріти й у інтернет-виданнях.

Отже, підсумовуючи, можемо зазначити, що на сьогодні в жанрі нарис відбулися певні трансформації: зменшення обсягу, збільшення ілюстрацій, додавання, за можливістю, відео та аудіозапису, насиченість порадами та корисною інформацією тощо. Проте як портретний, так і подорожній нарис не втратили своєї актуальності, а навпаки, все більше стають затребуваними суспільством. Незважаючи на достатню кількість досліджень, необхідно більш детально вивчати трансформаційні процеси жанрової форми, а також процеси взаємопроникнення жанрів, адже в нарисі достатньо часто з'являються інтерв’ю, звіт, репортаж, есе, а почасти - й аналітика. Такі жанрові суміші, безумовно, впливають на сприйняття матеріалу аудиторією. 


\section{REFERENCES}

1. Маслова Н. М. Путевые заметки как публицистическая форма / Н. М. Маслова. М.: Знание, 1977. 115 с.

2. Прокофьев Н. И. Хождение: Путешествие и литературный жанр // Книга хождений: Записки русских путешественников XI-XV вв. / Вступит. ст. подг. Текстов Н. И. Прокофьева. М.: Наука, 1984. С. 5-20.

3. Мартынова О. М. «Итальянское путешествие» Гете: Автор. композиция, жанр [Электронный ресурс] / О. М. Мартынова. Санкт-Петербург, 1995. Режим доступа к рсурсу: http://www.dissercat.com/content/italyanskoe-puteshestvie-gete-avtorkompozitsiya-zhanr

4. Полєжаєв Ю. Г. Розвиток просвітницької тревел-журналістики в Україні (середина XIX - початок XX століття) [Електронний ресурс] / Ю. Г. Полєжаєв // Держава та регіони. Сер. : Гуманітарні науки. 2012. С. 106-110. Режим доступу до ресурсу: http://nbuv.gov.ua/UJRN/drgn_2012_4_20

5. Borm J. Defining Travel: On the Travel Book, Travel Writing and Terminology // Perspectives on Travel Writing [G. Hooper, T. Youngs]. Aldershot: Ashgate, 2004. P. 13-27.

6. Тепляшина А. Н. Методологические основы жанрообразования в масс-медиа / А.Н. Тепляшина // Логос. Общество. Знак (К исследованию проблемы феноменологии дискурса): сб. науч. тр. / отв. ред. Б. Я. Мисонжников. СПб: БРИГ-ЭКСПО, 1997. C. $128-133$.

7. Рощектаева Т. Г. Жанрово-стилистические особенности современного путевого очерка: на материале русской публицистики 90-х годов XX века [Электронный pecypc] / Т. Г. Рощектаева, М., 2007. Режим доступу до рсурсу: http://www.dissercat. com/content/zhanrovo-stilisticheskie-osobennosti-sovremennogo-putevogo-ocherkana-materiale-russkoi-publ

8. Козьмин В. Жанр очерка / В. Козьмин // Литература в школе. 1985. № 1. С. 56-57.

9. Гусєва О. А. Сучасний подорожній нарис: особливості трансформації старого жанру [Електронний ресурс] / О. А. Гусєва; Вісник Львівського університету. Серія Журналістика. 2014. Випуск 39. С. 221-226. Режим доступу до ресурсу: http:// publications.lnu.edu.ua/bulletins/index.php/journalism/article/viewFile/5496/5503

10. Гриценко О. М. Основи теорії міжнародної журналістики / О. М. Гриценко, В. І.Шкляр. К.: ВПЦ «Київський університет», 2002. 304 с. 


\title{
TRANSFORMATION OF THE GENRE ESSAY IN NEW MEDIA
}

\author{
Antonina Ivashchuk \\ National Aviation University, \\ prosp. Kosmonavta Komarova, 1, 03680, Kyiv, Ukraine \\ e-mail: Iva.tonya@gmail.com \\ https://orcid.org/0000-0003-0209-148X
}

The article is devoted to the problems and prospects of development and further transformation of travel essay. The peculiarities of creation of a material which would be demanded by the audience are considered; the complex of factors determining the success of the essay in modern mass media is determined; selected approaches to the collection of unique information; generalized theoretical basis, as regards the definition of «essay». There is an urgent need for studies on the transformation of genre forms. Tendency to increase the popularity of new media and to reduce the target audience of print media, it becomes expedient to find out how to write a travel-publication or a portrait essay in such a way that they are interesting and popular to the audience. New media, of course, make it possible to use not only text, but also images, videos and audio. Today there is a tendency to reluctance of the audience to perceive large text forms, therefore the genre form needs to be modified and adapted to various channels of communication.

It's impossible to imagine a new media outline without photos, video or audio materials, virtual maps, infographics in general. In this way, the authors facilitate the perception of information and allow travel with them, or visualize the portrait of a person referred to in the portrait sketch.

Nowadays there is a modernization of the essay, the acquisition of new features and properties on the brink of the destruction of the traditional genre (essays, confession and autobiography). Sometimes, the author does not reveal himself in any way in the essay - either directly or indirectly, and the product does not lose integrity. Today, a many bloggers in social networks work in this genre: they write posts from their own travels where they share useful links, descriptions of interesting places, traditions and peculiarities of a country. Illustrated by a large number of photographs, sometimes giving tables and charts, comparing, arguing, convincing in their materials.

Key words: essay, travel essay, portrait essay, genres, target audience, new media, artistic and journalistic group of genres, social networks. 